\title{
EXTERNAL AUDIT IN NHS TRUSTS
}

\author{
Assistant PhD Student Iulian Dobra, “1 Decembrie 1918” University of Alba Iulia, \\ dobra.iulian@gmail.com
}

\begin{abstract}
External auditors for NHS trusts give an independent opinion on the trust's financial statements. They also review aspects of the arrangements that trusts have put in place to ensure the proper conduct of their financial affairs, and to manage their performance and use of resources. Special accountabilities attach to the use of public money and the conduct of public business. Auditors must carry out their work in accordance with the Audit Commission's Code of Audit Practice that is approved by the UK Parliament.
\end{abstract}

Keywords: Audit regulation; Corporate governance; NHS trusts; Audit independence; Audit quality

JEL Codes: III

\section{NHS Foundation Trusts}

NHS foundation trusts are a fundamental part of the current NHS reform programme in United Kingdom. They reflect the move from a centrally managed service towards one that is managed locally and so more responsive to patients.

NHS foundation trusts are:

- a new type of NHS organisation, established as independent public benefit corporations;

- free from central government control and from strategic health authority performance management;

- providers of healthcare according to core NHS principles - free care, based on need and not ability to pay;

- accountable to local people, who can become members and governors;

- free to innovate for the benefit of their local community and patients;

- able to decide for themselves what capital investment is needed in order to improve their services;

- free to retain any surpluses they generate and to borrow in order to support this investment; and

- $\quad$ authorised and monitored by Monitor ${ }^{1}$.

The first NHS foundation trusts were established in April 2004. There are currently 112 NHS Foundation Trusts. Monitor has adopted a risk-based approach to regulation.

\section{Regulations, acts for NHS Foundation Trusts}

\footnotetext{
${ }^{1}$ Monitor - also known as the Independent Regulator for NHS Foundation Trusts, is a non-departamental public body in the United Kingdom. Its purpose is to regulate NHS Foundation Trusts or Foundation Hospitals - hospitals that have opted out of direct governmental control. The body was established under the Health and Social Care (Community Health and Standards) Act 2003.
} 
Audit Code for NHS Foundation Trusts (the code), which is published by Monitor, prescribes the way in which auditors of NHS foundation trusts are to carry out their functions as set out in the National Health Service Act 2006 (the 2006 Act) ${ }^{2}$. This code applies to all audit work relating to financial years beginning on or after 1 April 2007. It is guidance which must be followed, as set out in Condition 22 of the Terms of Authorisation for NHS foundation trusts.

In the previous Audit Code for NHS Foundation Trusts, which was issued in December 2005, Monitor indicated that the code would be subject to review to take account of the implications arising from any new and relevant documents published. This revised code is the result of that review.

Table no. 1

Statutory responsibilities of Auditors of NHS foundation trusts

\section{Responsability}

To be satisfied that the accounts comply with the directions provided, i.e. that the accounts comply with The NHS Foundation Trust Financial Reporting Manual.

To be satisfied that the accounts comply with the requirements of all other provisions contained in, or having effect under, any enactment which are applicable to the accounts.

To be satisfied that proper practices have been observed in compiling the accounts.

To be satisfied that proper arrangements have been made for securing economy, efficiency and effectiveness in the use of resources.

To comply with any directions given by Monitor as to the standards, procedures and techniques to be adopted, i.e. to comply with the code To consider the issue of a public interest report

To certify the completion of the audit

To express an opinion on the accounts

To refer the matter to Monitor when an NHS foundation trust, or an officer or director of an NHS foundation trust, makes or is about to make decisions involving potentially unlawful expenditure or takes or is about to take potentially unlawful action likely to cause a loss or deficiency

\section{Derived from}

Schedule 10,

1(a)

Schedule 10,

1(b)

Schedule 10, 1(c)

Schedule 10, 1(d)

Schedule 7, 24

Schedule 10, 3

Schedule 10, 4(1)(a)

Schedule 10, 4(1)(b)

Schedule 10, 6

\section{Audit process}

\section{Audit scope}

In auditing the accounts of an NHS foundation trust the auditors must, by examination of the accounts and otherwise, satisfy themselves:

- that they are prepared in accordance with directions under paragraph 25(2) of Schedule 7 of the 2006 Act;

- that they comply with the requirements of all other provisions contained in, or having effect under, any enactment which is applicable to the accounts;

- that proper practices have been observed in the compilation of the accounts; and

- that the NHS foundation trust has made proper arrangements for securing economy, efficiency and effectiveness in its use of resources.

\footnotetext{
${ }^{2}$ National Health Service Act 2006 - Public Acts 2006 of the UK Parliament, Chapter 41, 8th November 2006,
} 
The following table demonstrates how the outcomes of the auditors' work to satisfy themselves in relation to the requirements above are reported:

Table no. 2

Requirement and scope of auditors' work

\begin{tabular}{|c|c|c|}
\hline $\begin{array}{l}\text { Requirement to satisfy themselves } \\
\text { that: }\end{array}$ & $\begin{array}{l}\text { Scope of } \\
\text { work }\end{array}$ & Reporting of material exceptions \\
\hline $\begin{array}{l}\text { The accounts are prepared in accordance } \\
\text { with directions under paragraph } 25(2) \text { of } \\
\text { Schedule } 7 \text { of the } 2006 \text { Act. }\end{array}$ & $\begin{array}{l}\text { Paragraph } \\
4.3 \text { (of the } \\
\text { code) }\end{array}$ & $\begin{array}{l}\text { Qualification of the audit opinion and } \\
\text { audit certificate Reporting in line with } \\
\text { ISAs (UK\&I). }\end{array}$ \\
\hline $\begin{array}{l}\text { The accounts comply with the } \\
\text { requirements of all other provisions } \\
\text { contained in, or having effect under, any } \\
\text { enactment which is applicable to the } \\
\text { accounts. }\end{array}$ & $\begin{array}{l}\text { Paragraph } \\
4.3 \text { (of the } \\
\text { code) }\end{array}$ & $\begin{array}{l}\text { Qualification of the audit opinion and } \\
\text { audit certificate Reporting in line with } \\
\text { ISAs (UK\&I). }\end{array}$ \\
\hline $\begin{array}{l}\text { Proper practices have been observed in } \\
\text { the compilation of the accounts. }\end{array}$ & $\begin{array}{l}\text { Paragraph } \\
4.3 \text { (of the } \\
\text { code) }\end{array}$ & $\begin{array}{l}\text { Qualification of the audit opinion and } \\
\text { audit certificate Reporting in line with } \\
\text { ISAs (UK\&I). }\end{array}$ \\
\hline $\begin{array}{l}\text { The NHS foundation trust has made } \\
\text { proper arrangements for securing } \\
\text { economy, efficiency and effectiveness in } \\
\text { its use of resources }\end{array}$ & $\begin{array}{l}\text { Paragraphs } \\
4.4-4.129 \\
\text { (of the } \\
\text { code) }\end{array}$ & $\begin{array}{l}\text { If the statement on internal control is } \\
\text { not consistent with the auditors' } \\
\text { knowledge of the NHS foundation trust, } \\
\text { the auditors must refer to this fact, and } \\
\text { the supporting reasons, in the audit } \\
\text { opinion and qualify the audit certificate. } \\
\text { If the statement of internal control is } \\
\text { consistent with the auditor's knowledge } \\
\text { but the auditor cannot conclude that the } \\
\text { NHS foundation trust has made proper } \\
\text { arrangements for securing economy, } \\
\text { efficiency and effectiveness in its use of } \\
\text { resources, the auditor must qualify the } \\
\text { audit certificate. }\end{array}$ \\
\hline
\end{tabular}

\section{Audit technical support and quality assurance}

\section{Technical support}

The financial results of NHS foundation trusts is included in Whole of Government Accounts (WGA). Whilst the NHS Foundation Trust Financial Reporting Manual ${ }^{3}$ provide guidance on the format of the financial statements and the appropriate accounting principles to adopt in the preparation of the financial statements.

It is therefore important to ensure consistency between different auditors in the approach taken to particular accounting issues, whilst not reducing the independence of the auditor to conclude on the audit.

Each audit supplier appointed as auditors of NHS foundation trusts must therefore ensure senior participation in a technical issues forum. This forum will consider technical auditing and accounting issues relevant to NHS foundation trusts. Whilst auditors are not required to comply with the decisions made by this forum, any differences in auditing judgement or opinion likely to

\footnotetext{
${ }^{3}$ NHS Foundation Trust Financial Reporting Manual for 2008/2009 ( FT FreM) has been edited in 23 september 2008, Monitor (September 2008), Publication code: IRG 08/08.
} 
lead to material variation in the reported results across NHS foundation trusts must be reported to Monitor for information, together with an explanation for the reasons why the forum's guidance has not been followed.

In addition to Monitor's representative(s) and the senior representatives from each of the audit suppliers appointed as auditors of NHS foundation trusts, each of the following organisations will be invited to send a representative to the forum:

- National Audit Office;

- Audit Commission;

- Department of Health; and

- HM Treasury.

\section{Monitoring arrangements}

As NHS foundation trusts are classified as being in the public sector, the work of auditors in performing an audit of NHS foundation trusts will not be subject to the external quality monitoring regimes of audit suppliers' commercial audits. Monitor, however, will want assurance that the audit complies with the code and that it is of a suitable quality. In addition, the Comptroller and Auditor General C\&AG will need to know that reliance can be placed on the work of the NHS foundation trust auditors for the WGA process.

Auditors must comply with the monitoring regime set up by Monitor with the ICAEW Quality Assurance Directorate.

The results of the monitoring must be reported to the audit firm involved, with a copy of the report being sent to Monitor.

\section{Cooperation with other bodies}

In discharging their duties, the auditors will need to cooperate with other relevant regulatory bodies and the auditor of the consolidated accounts of NHS foundation trusts.

The Comptroller and Auditor General ${ }^{4}$ (C\&AG) of the National Audit Office ${ }^{5}$ (NAO) has the right to examine the accounts, any records relating to them and any report of the auditor on them. In addition, the C\&AG has a duty in relation to value for money within the NHS. The auditors must, where requested, provide the $C \& A G$ with the report on the accounts. The C\&AG request the accounts or records relating to them from the NHS foundation trust itself. A memorandum of understanding between the C\&AG and the auditors of NHS foundation trusts is included at appendix D in the code and auditors of NHS foundation trusts are required to comply with it.

\footnotetext{
${ }^{4}$ The Comptroller and Auditor General -The unabbreviated title in the United Kingdom is Comptroller General of the Receipt and Issue of Her Majesty's Exchequer and Auditor General of Public Accounts. The role was first created in the United Kingdom by the Exchequer and Audit Departments Act 1866 which combined the functions of the Comptroller of the Exchequer, (who had authorised the issue of public monies to departments since 1834) with those of the Commissioners of Audit, (who had traditionally presented the government accounts to the Treasury). Under the terms of the act the Comptroller and Auditor General continued to authorise the issue of money to departments (the Comptroller function) and was given the new task of examining departmental accounts and reporting the results to Parliament. In the United Kingdom the Comptroller and Auditor General is an officer of the House of Commons who is the head of the National Audit Office.

${ }^{5}$ The National Audit Office (NAO) is an independent Parliamentary body in the UK which is responsible for auditing central government departaments, government agencies and non-departamental public bodies. The NAO also carries out Value for Money (VFM) audit into the administration of public policy, although not into the merits of policy objectives themselves.
} 
The Healthcare Commission ${ }^{6}$ will be responsible for undertaking inspections and studies of economy, efficiency and effectiveness of NHS foundation trusts. The auditors should receive information from the Healthcare Commission in relation to the performance of the NHS foundation trust and must consider the implications of this information for their audit. As specified in the code (paragraph 4.8), auditors of NHS foundation trusts should discharge their responsibility surrounding economy, efficiency and effectiveness of NHS foundation trusts by undertaking any specified pieces of work mandated by the Healthcare Commission. Monitor and the Healthcare Commission have agreed that a formal relationship i.e. a Memorandum of Understanding between the Healthcare Commission and the NHS foundation trust auditors may be negotiated in the future.

The Audit Commission ${ }^{7}$ appoints auditors to other NHS bodies. The appointed auditors to other NHS bodies within a local health economy which includes an NHS foundation trust may wish to liaise with the auditors of the NHS foundation trust in order to discharge their responsibilities as set out in the Audit Commission's Code of Audit Practice. This may particularly be the case in relation to the appointed auditors of strategic health authorities and primary care trusts. In this instance, the auditors of the NHS foundation trust may respond to any liaison requests, after obtaining permission from the NHS foundation trust. In conclusion the auditors of the NHS foundation trusts may implement legal agreements as deemed appropriate in the individual circumstances.

\section{References:}

1. Audit Code for NHS Foundation Trusts -edited by Monitor Independent Regulator of NHS Trusts, October 2007, IRG 06/07, United Kingdom;

2. NHS Foundation Trust Financial Reporting Manual 2008/09 (FT FReM) edited by Monitor Independent Regulator of NHS Trusts, September 2008, IRG 08/08, United Kingdom;

3. www.nao.org.uk;

4. www.opsi.gov.uk/acts

5. www.audit-commission.gov.uk

6. www.healthcarecommission.org.uk

7. www.wikipedia.org.

\footnotetext{
${ }^{6}$ The Healthcare Commission is a non-departamental public body sponsored by the Departamen of Health of the UK. It was set up to promote and drive improvement in the quality of health care and public health in England and Wales. It aims to achieve this by becoming an authoritative and trusted source of information and by ensuring that this information is used to drive improvement.

${ }^{7}$ The Audit Commission is a public corporation in the UK, established under the Local Government Finance Act 1982 , to appoint auditors to all local authorities in England and Wales. The National Health Service and Community Care Act 1990 extended the remit of the Commission to cover health service bodies. Legislation covering the Commission's activities was consolidated into the Audit Commission Act 1998. One of the Commission's primary objectives is to improve economy, efficiency and effectiveness in local government and the health service, directly through the audit and inspection process and also through value for money studies. Since 1 April 2005 the Commission's functions in Wales have been the responsibility of the Auditor General for Wales.
} 